\title{
7
}

\section{Rural financial markets and institutions: new developments}

\section{Enjiang Cheng}

Continuous declines in the growth rate of farmers' incomes and widening income gaps between urban and rural areas since the early 1990 s have renewed interest in China's agricultural and rural development. Rural fiscal and taxation policies, including the massive debts owed by the township and village administrations, and rural financial policies have topped the agenda for further rural economic reforms in 2003. The Central government has been urged to reduce the ever-increasing burdens on farmers through fiscal and taxation reforms and to provide more credit for rural development by introducing new reforms to rural financial institutions and markets.

China's rural financial market is dominated by formal rural financial institutions, especially in the savings markets, as the deposits of formal financial institutions are insured by the state. The formal financial market and its institutions are highly regulated, with government regulations on rates of interest, market entry and exit, financial products and lending methodologies. Like their counterparts in urban areas, China's rural financial institutions have for a long time been marred by poor financial performance and high proportions of non-performing loans.

Rural financial institutions in China can be divided into formal and informal institutions. Formal rural financial institutions in China consist of the Agricultural Bank of China $(A B C)$, the Agricultural Development Bank of China (ADBC), rural credit cooperatives (RCCs) and Rural Postal Savings (RPS). Of them, ADBC is a 
policy bank in agriculture and RPS are savings-only financial institutions attached to Post Offices. Rural credit cooperatives are credit cooperatives based at township level, and township rural credit cooperatives are profit centres and legal persons. Informal finance in rural China, defined as the financial intermediaries and transactions unregulated by the People's Bank of China (PBOC), consists mainly of credit transactions among relatives and friends, by moneylenders, and informal financial mechanisms organised by rural households, such as revolving savings and credit associations, as well as institutional informal finance (Cheng and $\mathrm{Xu}$ 2003). Institutional informal finance includes rural credit foundations (RCFs) and other financial institutions organised by local governments, as well as donor-funded microfinance institutions (MFIs). ${ }^{1}$

This chapter focuses on the operation of formal rural financial institutions, mainly rural credit cooperatives, the $A B C$ and formal financial markets in China. The major challenges to China's rural financial system since the middle 1990 s and the attempts by the Chinese government and others to create an efficient rural financial system responsive to the demand from farmers and rural enterprises are reviewed in the chapter.

\section{THE CHALLENGES}

\section{Declines in credit supply}

The outflow of funds from rural areas channelled through formal rural financial institutions and declines in the supply of rural credit have been identified as major obstacles to China's rural development (Zhang 2003). The shortage of rural formal credit has been blamed for the slow pace of rural structural adjustment in developed areas of China (Xinhua News Agency, 27 April 2002). Woo (2003) argued that the slowdown of TVE growth, which has contributed to a slower growth in China since 1996 , has been closely related to the operation of the rural financial system. The shortage in the supply of institutional credit has also been blamed for the problems in the major agricultural areas of China. For example, in a report submitted to the Monetary Policy Committee of the People's Bank of China, Wen (2001) argued that, in poor areas, a growing number of poor households have been trapped in a debt cycle and forced to provide labour to moneylenders to cover interest repayments.

Using official statistics, we found that the actual supply of institutional credit as a proportion of rural deposits in rural China has declined significantly since the mid 
1990s. This is despite continuous increases in year-end loans outstanding in rural financial institutions (Cheng and Xu 2003). In Table 7.1, we attempt to track the actual flows of rural credit funds by considering deposits from rural households to be rural deposits and the ABC's loans to agriculture and TVEs and all rural credit cooperative loans as rural lending. In Table 7.1, rural household deposits include deposits from the rural household sector to all formal financial institutions in China, including rural postal savings. We further assume that it is annual loan disbursements rather than year-end loans outstanding that affect the supply of institutional credit, and, second, that the ADBC loans should not be counted as rural lending because they are not provided to rural households and enterprises.

As a proportion of total household deposits, the institutional lending in rural China has halved in the last decade (Table 7.1). The decline has been consistent over time, and the steeper declines in the ABC's agricultural lending have been offset to some extent by lending from rural credit cooperatives. As a consequence, over 70 per cent of total rural institutional lending has been from rural credit cooperatives, which makes the $A B C$ a relatively insignificant player in financing households and TVEs in rural China. Moreover, the decline in the ratio of rural lending to rural deposits

Table 7.1 Changes in rural deposit savings and loans, 1991-2001 (Billion yuan at current prices)

\begin{tabular}{ccccccc}
\hline & $\begin{array}{c}(1) \\
\text { Total rural } \\
\text { deposits }\end{array}$ & $\begin{array}{c}(2) \\
\text { ABC annual } \\
\text { disbursement }\end{array}$ & $\begin{array}{c}(1) /(2) \\
\text { (per cent) }\end{array}$ & $\begin{array}{c}\text { RCCs annual } \\
\text { disbursement }\end{array}$ & $\begin{array}{c}\text { ABC \& RCC } \\
(4) /(1)\end{array}$ & $\begin{array}{c}\text { disbursement } \\
\text { (pent) }\end{array}$ \\
1991 & 611 & 170.6 & 27.9 & 259.4 & 42.5 & 70.4 \\
1996 & 1848 & 317.2 & 17.2 & 794.3 & 43.0 & 60.1 \\
1997 & 2282 & 344.1 & 15.1 & 879.9 & 38.6 & 53.6 \\
1998 & 2660 & 270.7 & 10.2 & 796.5 & 29.9 & 40.1 \\
1999 & 3011 & 234.6 & 7.8 & 871.8 & 29.0 & 36.7 \\
2000 & 3428 & 179 & 5.2 & 952.4 & 27.8 & 33.0 \\
2001 & 4106 & 201.5 & 4.9 & 1087 & 26.5 & 31.4 \\
\hline
\end{tabular}

Notes: ${ }^{1}$ Total household deposits by all RFIs in China. ${ }^{2}$ Annual loan disbursement by the ABC for Agriculture and TVEs, including the poverty loans. ${ }^{4}$ Annual RCC loan disbursement. $5=(2+4) / 1 * 100$.

Sources: Calculated from Statistical Yearbooks of China's banking and Finance, People's Bank of China, 1992 to 2002. 
would be more drastic if loan refinancing and rescheduling were taken into account. It is also important to note that the aggregate rural lending figures conceal regional variations and flows of funds from poorer to richer areas, a topic deserving further study.

\section{Financial performance and historical burdens}

Declines in the supply of institutional credit in rural China have been caused largely by the deteriorating financial performance of rural financial institutions and the pressure for commercialisation of the Agricultural Bank of China. According to rural credit cooperatives, most losses and non-performing loans have been caused by historical factors and other developments beyond their control. Hence, the cumulative financial losses and non-performing loans of rural credit cooperatives are called historical burdens. $\mathrm{He}(2001)$ reported that about half of all rural credit cooperatives in China have been operating at a financial loss. It was further estimated that the ratio of non-performing loans in the rural credit cooperative system has exceeded 35 per cent ( $\mathrm{Li} 2000$ ). The performance of rural financial institutions in poor and major agricultural areas was usually worse than the national average. Our field investigations show that the performance of many branches of the Agricultural Bank of China's, especially those in poor areas, is not necessarily better than that of the rural credit cooperatives in these areas.

According to a study by the PBOC branch in Tongren Prefecture of Guizhou Province, the cumulative financial losses of rural credit cooperatives in the prefecture had reached 81 million yuan and the ratio of non-performing loans had reached 53.7 per cent by the end of 2000 . In Dejiang County of the prefecture, the ratio of nonperforming loans had reached 87.8 per cent. Cumulative financial losses had reached 20.7 million and were increasing at a rate of 1 million per annum (Tongren PBOC 2001). Our field investigations in China indicate that the rural credit cooperatives in Tongren could be regarded as representative of many rural credit cooperatives in the poor areas of China. We also found that, following the increases in non-performing loans and financial losses, many rural credit cooperatives have negative net worth and are technically bankrupt.

Because the Agricultural Bank of China was a state-owned bank, the Central Government accepted responsibility for its historical burdens and shifted its bad loans to an asset management company. It is unclear, however, who will be responsible for the massive historical burden of the rural credit cooperatives. Owing 
to problems with the definition of, and collection of information on, non-performing loans, no one knows the actual amount of uncollected loans and the true financial losses of rural credit cooperatives in China. It will be difficult for rural financial institutions to increase their rural lending if the so-called historical burdens are not resolved.

\section{Distortions in rural financial markets}

Since the early 1990s, the Chinese government has made progress in relaxing direct state control over interest rates and removing market distortions caused by negative real rates of interest. Real deposits and lending rates rose from 1989 to 1998 and declined slightly thereafter (Table 7.2). Moreover, the difference between the rates for demand deposits and time deposits has narrowed consistently, and the term structure for deposit rates has become less skewed. Real lending rates for rural lending have also turned from negative to positive in the last decade. The major officially subsidised loans are poverty loans and the agricultural on-lending provided by rural credit cooperatives. The rate differential between one-year lending and deposits has increased over time, leaving a higher margin for rural financial institutions. These changes do suggest a process of financial deepening (McKinnon 1973; Shaw 1973), which is thought to have contributed to the increases in savings deposits and resource allocation in rural China.

Table 7.2 Changes in real institutional rates of interest, 1989-2002 (per cent)

\begin{tabular}{lccccccc}
\hline & Feb 89 & Apr 91 & Jul 93 & Jul 95 & Jul 97 & Jun 99 & Feb 02 \\
Deposits & -12.7 & -1.1 & -8.9 & -11.2 & 0.9 & 4.1 & 2.0 \\
Demand & -7.5 & 2.4 & -3.7 & -8.2 & 3.3 & 5.3 & 3.2 \\
6 month & -5.5 & 4.5 & -2.0 & -6.4 & 4.8 & 5.4 & 3.3 \\
12 month & -4.0 & 5.2 & -0.8 & -5.7 & 5.4 & 5.9 & 3.9 \\
3 years & -2.4 & 5.9 & 0.6 & -5.1 & 5.8 & 6.1 & 4.1 \\
5 years & & & & & & & \\
Loans & -5.5 & 5.1 & -3.7 & -4.1 & 6.8 & 8.8 & 6.4 \\
6 months & -5.5 & 5.6 & -2.0 & -2.4 & 7.8 & 9.1 & 6.7 \\
12 months & -5.5 & 4.7 & -2.8 & -3.2 & 6.9 & & \\
Agriculturalprocurement & -12.7 & 0.0 & -9.1 & -10.4 & 2.1 & 6.2 & 4.4 \\
Subsidised poverty loans & 17.8 & 2.9 & 13.2 & 14.8 & 0.8 & -3 & -1.3 \\
Inflation (p) & & & & & & & \\
\hline
\end{tabular}

Notes: Real rates of interest are calculated using the formula: $r=(i-p) /(1+p)$, where $r=$ real interest rates, $i=$ nominal rate of interest, $p=$ annual increase in general retail prices.

Sources: PBOC, 2002. Almanac of China's Finance and Banking, 1990-2002, People's Bank of China, Beijing. 
Nevertheless, distortions in China's rural financial market remain, as institutional rates of interest are still determined administratively, with little regard for the costs and risks of lending. Real rural lending rates (Table 7.2), although raised over time, have been low compared with the market rate of interest, as reflected by rates in the informal financial markets (around 20-25 per cent nominal). Moreover, the rates have been lower in terms of the high costs and high risks for rural lending in China. I project sustainable lending rates for rural financial institutions of 8.8 per cent in coastal areas, 11.5 per cent in major agricultural areas and 16 per cent in poor areas of China, all of which are much higher than official lending rates. Clearly, institutional lending in rural China is generally not profitable under the current structure of institutional interest rates. ${ }^{2}$ in other words, the more rural financial institutions lend, the more losses they will incur. Low lending rates of interest have already contributed to financial losses in rural financial institutions, and these are accumulating over time. Moreover, low lending rates and low interest margins have limited the volume of operational funds available for rural financial institutions, leading in turn to rises in the proportion of non-performing loans and hence declines in the supply of rural funds for lending. On the assumption that rural financial institutions are responsive to interest rate signals, rural financial institutions will reduce their rural lending and shift the funds out of rural areas unless the government regulates their lending and use of funds.

\section{Ownership structure and corporate governance}

Soft budget constraints and implicit deposit insurance give rise to a moral hazard problem for rural financial institutions in China. Xie Ping (2001) argued that rural credit cooperatives are not real credit cooperatives. The ownership of rural credit cooperatives is further complicated by the fact that many have a negative equity. In other economies, where banks have a more clearly defined ownership structure, bankruptcy is a hard constraint for any financial institution. But rural credit cooperatives face soft budget constraints. Chinese regulators have been very cautious about closing rural credit cooperatives and have sometimes bailed individual cooperatives out when they have had a payment problem.

Rural credit cooperatives in China face soft budget constraints for several reasons. First, given state regulation of the rate of interest and barriers to market entry, rural 
credit cooperatives have become predominant in the supply of financial services to farmers following the gradual withdrawal of the Agricultural Bank of China from rural townships. Closure of poorly performing rural credit cooperatives could lead to the complete absence of formal financial services in some rural areas. Second, with the collapse of producers and marketing cooperatives and recent difficulties with agricultural extension services, rural credit cooperatives-as a link between the state and farmers - have become one of the major vehicles for the Central Government to carry out its agricultural support policies. Third, with large amounts of deposits from low income farmers and the absence of explicit deposit insurance from the government or any other body, closure of rural credit cooperatives could cause serious political and social unrest. Therefore, bankruptcy of rural credit cooperatives is socially and politically unpalatable (Xie Ping 2002).

With soft budget constraints and deposit insurance implicitly provided by the state, rural credit cooperatives definitely face a moral hazard problem. Moral hazard has occurred at the following three levels. At the local level, local governments tend to adopt the strategy of levying high taxes and fees on rural credit cooperatives because they are aware that the Central Government will not let rural credit cooperatives go bankrupt. At the cooperative level, management and staff of rural credit cooperatives may not be concerned about performance and profitability and may extend risky loans. At the borrower level, borrowers, especially enterprise borrowers, find it easier to persuade loan officials to soften their loan terms. The possibility of collusion between RCC management and local governments and between the loan officials and their clients for mutual benefit, at the cost of the state, cannot be ruled out.

The same moral hazard problem occurred with the Agricultural Bank of China. The Agricultural Bank of China has been trapped in a cycle of centralisation and decentralisation of lending decisions. Decentralisation, which allows institutions to process and use local information more effectively, gave rise to local government intervention on loan decisions and possible collusion between loan officials and clients. But centralisation makes the loan application process long and complicated, which discourages rural enterprises and households from applying. In addition to the interest rate distortions, the moral hazard problem is an important reason for the continuous decline in the Agricultural Bank of China's lending to rural enterprises and households. ${ }^{3}$ 


\section{Lack of competition in rural financial markets}

Competition in China's rural financial markets is constrained by state regulation on the entry and exit of financial institutions. The Agricultural Bank of China, the Agricultural Development Bank of China and rural credit cooperatives are the only state-sanctioned legal rural financial institutions. Of them, the Agricultural Bank and the Agricultural Development Bank are government-owned financial institutions and rural credit cooperatives, albeit defined as cooperatives, are subject to PBOC regulation and management and have a corporate governance structure similar to those of state-owned financial institutions. Entry by new financial institutions is next to impossible. ${ }^{4}$ Moreover, there is no defined mechanism for individual lossmaking rural credit cooperatives with negative equities to exit the market. ${ }^{5}$ Restrictions on competition and exit are expected to contribute to the moral hazard problems for rural financial institutions in China (Cheng and Xu 2003).

It is difficult for the central authorities to tackle individually any of the challenges discussed above, as many problems are interrelated and the rural financial market is closely related to other markets in China. An immediate issue facing the Central Government is the historical burden of rural credit cooperatives. To mitigate moral hazard, it is necessary for the government to classify and remove these historical burdens. Otherwise, the rural credit cooperatives will pool the newly generated nonperforming loans and financial losses into historical burdens. ${ }^{6}$

Due to problems with reporting, monitoring and auditing it is extremely difficult for the government to distinguish between non-performing loans and financial losses of rural credit cooperatives caused by policy factors, and those caused by mismanagement. Given the scale of the problem the government would have to issue more bonds to write off all the historical burdens of rural credit cooperatives. ${ }^{7}$ Even if the government can write off all the bad loans by issuing more bonds, simply writing off the historical burdens of rural credit cooperatives will exacerbate the already serious moral hazard problem among rural financial institutions in China. In terms of the sustainable rate of interest, when the lending rate of interest is liberalised the rate charged by rural financial institutions will tend to jump higher in the less developed areas of China, precisely the areas where farmers can least afford it. Moreover, interest rate liberalisation alone can hardly improve the performance of rural financial institutions. Changes in corporate governance and the introduction of effective monitoring and supervision are required. 


\section{FINANCE FOR POVERTY ALLEVIATION: EXPERIMENTS IN MICROFINANCE}

Up to the mid to late 1990 s, the reforms of China's rural financial system were characterised by institutional changes, with little change in financial prices and lending methodologies. The fundamental changes to financial prices and lending methodologies were initiated by donors with the introduction of the Grameen Model microfinance in China in the early and mid $1990 \mathrm{~s}^{8}$ As the central and local authorities in China have adopted a non-interventionalist policy towards donor-supported microfinance programs, these programs have been in a unique position to set higher lending rates and test new lending methodologies for rural loans in China. ${ }^{9}$

Microfinance programs conducted experiments in new lending methodologies ahead of both the formal and informal financial institutions in China. The loans provided by rural financial institutions in China prior to the late 1990s were mainly term loans with low interest rates and relatively large loan sizes, and these loans were backed with neither collateral nor guarantees for loans. Other mechanisms for loan repayment, such as dynamic incentives and the targeting of women, were not in place. Loans provided by the microfinance programs in China (modified Grameen replicates) have been characterised by small loan sizes (about 500-3,000 RMB per loan), relatively high interest rates, frequent centre meetings and loan repayments, dynamic incentives and the targeting of women borrowers. Some programs have adopted group guarantees, deducting five per cent of the principal as a group fund deducted at the time of loan disbursement and initiating compulsory savings programs. Compulsory savings and group funds could be regarded as substitutes for collateral substitutes. Some new lending methodologies, such as dynamic incentives, the targeting of women and frequent loan repayment, have proved effective in raising loan repayment rates for small-size loans to rural households. These experiments also show that market mechanisms, such as market rates of interest, direct screening, peer selection and peer monitoring are useful means for delivering and collecting loans for poverty alleviation.

Microfinance programs have also tested higher lending rates for poverty alleviation loans. Most donor-funded programs in China charge an effective rate of interest from 12-18 per cent per annum, which is much higher than the rate charged by rural financial institutions in China (3-8.5 per cent per annum). The experiments with microfinance show that the current lending rates of interest regulated by the People's 
Bank of China are not able to cover the full costs for small scale rural financial institutions that provide small-size loans to the poor. The microfinance experiments in Henan and Hebei provinces of Central China undertaken by Funding the Poor Cooperatives (FPC) indicate that, in order to be viable, microfinance institutions in these areas need to charge an effective nominal lending rate of about 15 per cent. ${ }^{10}$ Moreover, microfinance institutions in China like the Funding the Poor Cooperative have no historical burdens or tax obligations, and the loan repayment rates of the Funding the Poor Cooperative's programs are much higher than those of the average rural credit cooperative in China (Cheng 2003).

A significant but less evident contribution of the microfinance movement is the creation of new forms of institution and a new approach to poverty alleviation, social welfare and financial development in China. The conventional approach in China is that the provision of financial services, poverty reduction and social welfare are the responsibility of governments and their institutions. The development of the microfinance movement in China demonstrates that semi-official institutions and NGOs can be equally effective, and in some cases more effective and innovative, in delivering public benefits.

The experiments in China's microfinance also show a number of constraints for financial development and poverty alleviation in rural China. First, it is difficult for any credit programs and institutions to be operationally and financially viable in the poor and remote mountainous areas of China's southwest and northwest, because they face very high transaction costs and a lack of income generation and investment opportunities in these areas. Second, China's microfinance experiments so far are largely program based rather than institution based, and many are run by temporary project management offices. In other words, the microfinance movement so far has failed to test a new form of institution based on a clearly identified ownership structure and good corporate governance, and committed to providing long-term sustainable financial services to the poor and others in rural China. Finally, there has not been effective external monitoring, supervision and auditing of microfinance programs and institutions, which makes the long-term development of the microfinance movement in China difficult. Good corporate governance and effective external monitoring and supervision are also two major obstacles to institutional development in China's rural financial markets. 


\section{REFORMS TO FORMAL FINANCIAL MARKETS}

Parallel to the development of microfinance a number of reforms to the formal financial markets have been undertaken. The overall objective of these reforms was to separate policy, cooperative and commercial finance in order to commercialise the operation of the Agricultural Bank of China, and hence to improve the operation of rural financial institutions in China. "In 1994, the Agricultural Development Bank of China was created and charged with the responsibility of managing policy loans, which at that time comprised of loans for agricultural procurement, storage and processing and integrated agricultural development and poverty alleviation (ADBC 1994). The comprehensive financial reforms launched in 1996, which separated rural credit cooperatives from the Agricultural Bank of China, advanced the Agricultural Bank of China towards commercialisation. The management of rural credit cooperatives was shifted first to a newly established Inter-ministerial Coordination and Leading Group for Rural Financial Reforms in 1996, which then joined the People's Bank of China in 1997 (Almanac of China's Finance and Banking 1998). After the separation, rural credit cooperatives were supervised and managed by the People's Bank of China, however, after a marked deterioration in loan quality, the Agricultural Bank of China took back the management of subsidised poverty loans (an important part of Chinese agricultural policy) in 1998.

To commercialise its operations the Agricultural Bank of China not only rationed credit supply in rural areas but also transferred its funds from relatively poor to richer areas. From 1995 to 2001 , it reduced its staff by around 13 per cent and its branches and business offices by 34 per cent. Many of the closed branches and business offices were located in rural townships. By reducing its rural lending the Agricultural Bank of China has diversified its portfolios, shifted its lending focus to urban and coastal areas and developed its off balance sheet transactions. According to the President of the Agricultural Bank of China consumer loans have increased substantially since 1997 (Almanac of China's Banking and Finance 2002:30), including mortgage loans, automobile loans and loans for house renovations. The major losers of the Agricultural Bank of China's credit rationing are township and village enterprises and those rural households engaging in off-farm production and investment (Cheng and Xu 2003). 
The Agricultural Bank of China was forced to take over the poverty loans from the Agricultural Development Bank of China in 1998, a setback on the institutional reforms initiated by the Central Government from the early 1990s. Since then, the Agricultural Bank of China has adopted a number of microfinance methods in some areas to reach the poor and raise repayment rates. These methods include providing small size loans for short terms (usually less than a year) and group guarantees. The overall repayment rate on Agricultural Bank of China's poverty loans is still very low, as it has insufficient staff and other resources at the township level to deal with thousands of individual borrowers. With a ceiling of three per cent per annum the Agricultural Bank of China is not allowed to raise the lending rate of poverty loans.

Another major event in rural finance since the mid 1990s is the closing of rural credit foundations. ${ }^{12}$ Since the financial reforms in the mid 1990 s, there have been increasingly frequent reports of a payment crisis with rural credit foundations. In 1999 the State Council ordered a nationwide termination of rural credit foundations. This was accompanied by a thorough auditing of rural credit foundation deposits and loans, which revealed serious problems with uses of the funds by the foundations in some parts of China. According to a study in Chongqing (Chen et al. 1999), of the total loan portfolio of rural credit foundations in the city ( 8.6 billion RMB), nearly 90 per cent should be regarded as non-performing when measured according to the bank standard and RCF rules. The same study indicates that local governments in the city borrowed more than one billion RMB from rural credit foundations and used the funds to invest in rural infrastructure. A high proportion of these loans to local governments were non-performing.

Nationwide, governments dealt with rural credit foundations in the following two ways. First, according to their financial position and loan quality: they merged the better-managed foundations with rural credit cooperatives, and the cooperatives took over all their loans and deposits. Second, they closed the other foundations and made local governments responsible for the repayment of deposits to small farmers. Because local governments have been forced to pay for the deposits of rural credit foundations, the closure of the foundations has had a large impact on local budget and local government debts, and, therefore, on the operation of local governments and government investment in rural infrastructure. Many local governments negotiated with the People's Bank of China and rural credit cooperatives and attempted to shift some of their financial burdens to the rural credit cooperatives. 
Consequently, there has been enormous pressure from some local governments for rural credit cooperatives to take over both the loans and deposits of rural credit foundations.

Since the early 1990 s, the central authorities have also relaxed direct control over interest rates for rural financial institutions. The central piece of the reform allows financial institutions to adjust their lending rates. In 1992, state banks and financial institutions were allowed to float their lending rates around the base rate for working capital loans, with an upper band of 20 per cent and a lower band of 10 per cent. On 1 June 1996, the state removed its control over the rates on the inter-bank money market rates (Dai Xianglong 1997:58). Then in 1998, they increased the interest band for the loans to SMEs from 10 to 20 per cent and the band for RCC lending from 40 to 50 per cent. ${ }^{13}$ In 1999, all the financial institutions and their branches operating at or below the county levels were allowed to float their lending rate by a maximum of 30 per cent, and the band for loans to SMEs was also raised from 20 to 30 per cent. As discussed above, despite the changes, the official lending rate was still far below the sustainable lending rate for rural financial institutions in many areas of China.

These institutional and market changes had a large impact on rural credit cooperatives in China. ${ }^{14}$ First, the gradual withdrawal of the Agricultural Bank of China from rural areas and the closure of rural credit foundations made rural credit cooperatives the dominant supplier-and in many agricultural areas the sole supplier - of institutional credit in rural China. Second, the quality of loans in the rural credit cooperative system deteriorated further as some rural credit cooperatives were persuaded or forced by local governments to take over RCF loans and obligations. Rural credit cooperatives were also under pressure from the Ministry of Agriculture and local governments to provide more loans to increase rural incomes and output. For example, the Ministry of Agriculture (2002) proposed to raise the amount of agricultural lending by setting the minimum amount of agricultural loans to be disbursed by financial institutions and increasing the variety and quantity of policy loans for agriculture. It also proposed to extend the loan duration and reduce the loan rate (so as to reduce the costs to borrowers) for rural lending in China.

Many rural credit cooperatives, especially those in poor and major agricultural areas of China, are struggling to survive. It is not possible for these rural credit cooperatives to increase their loans for agriculture. As a result, the People's Bank of China in 1998 had to introduce an agricultural on-lending program by providing 
cheap loans to rural credit cooperatives (at 2 per cent per annum). The value of these on-lending funds grew from 15 billion in 1999 to 20 billion RMB in 2001. The People's Bank of China stipulates that the on-lending fund can only be used for micro-loans to rural households for income generation activities. To reduce their costs, the rural credit cooperative system had undergone similar changes to the Agricultural Bank of China. From the mid 1990s to 2000, the number of township level rural credit cooperatives in China fell by about a quarter (He 2001).

\section{REFORMS OF RURAL CREDIT COOPERATIVES_PILOTS}

In an effort to tackle the deeply rooted problems in China's rural credit cooperatives, the Central Government and the People's Bank of China have launched a number of experiments for rural credit cooperative reforms since 2000. These experiments include the Pilot Rural Credit Cooperative reforms in Jiangsu Province, partial interest liberalisation for rural credit cooperatives in a number of provinces and promotion of microfinance within the rural credit cooperative system. ${ }^{15}$

\section{Pilot reforms in Jiangsu}

The pilot reforms in Jiangsu have three major objectives. First, to improve the corporate governance and management of rural credit cooperatives. Second, to eliminate the historical burdens and third, to make rural credit cooperative operations financially viable. The pilot reforms in Jiangsu Province, a relatively developed province in coastal China, include

- merging township level rural credit cooperatives into county rural credit cooperative unions and making rural credit cooperative unions the legal person and profit centre so as to expand the operational scale for rural credit cooperatives and reduce the tax burden

- in coastal areas of the province, turning the rural credit cooperative unions with good management and financial performance into rural commercial banks (RCBs)

- establishing the Provincial Rural Credit Cooperative Federation ${ }^{16}$

- providing interest free on-lending to the rural credit cooperatives in Jiangsu for five years to help reduce historical burdens.

By merging individual rural credit cooperatives into the county Rural Credit Cooperative Union and establishing the provincial Rural Credit Cooperative Federation, the PBC would be able to transfer its management function to the Rural Credit Cooperative Union and the provincial federation. This would allow the PBC to 
concentrate on monitoring and supervising rural credit cooperatives. By merging into rural credit cooperative unions, rural credit cooperatives would be able to allocate their funds in a county and achieve economies of scale in their operations. The experiment on the cooperative-to-stock conversion in the three counties (privatisation) was aimed at improving corporate governance and eliminating the moral hazards faced by rural credit cooperatives in rich areas of China.

Pilot reforms were initiated in Jiangsu in 2000. By early 2003, all township rural credit cooperatives had been merged into rural credit cooperative unions and the provincial Rural Credit Cooperative Federation had been established and had begun to function. The rural credit cooperative unions of Chagshu, Jiangyin and Zhangjiagang counties have been converted into rural commercial banks. ${ }^{17}$ It was reported that, following the reforms, the deposits and loan portfolio in the province have grown and the proportion of non-performing loans was falling. The full impact of the pilot reform on rural credit cooperative efficiency, the operation of rural financial markets in Jiangsu and the suitability of the pilot for rural credit cooperatives in other parts of the country remain to be studied.

\section{Partial interest rate liberalisation}

At the beginning of 2002, the People's Bank of China selected eight counties in rural China for a pilot on partial interest rate liberalisation. In these pilot areas, rural credit cooperatives are allowed to float their deposit rate by up to 50 per cent around the official base rate and to float their lending rate by up to 100 per cent around the base lending rate. No financial institution in China is allowed to float the base deposit rate. Rural credit cooperatives are allowed to float their lending rate by 50 per cent only around the base lending rate. The major purpose of the experiment is for rural credit cooperatives to be able to retain rural funds in local areas for agricultural supports and to help rural credit cooperatives achieve financial viability. Following the reform, rural credit cooperatives should be able to organise more funds from local areas, expand their operations and push down the high rates of interest charged by moneylenders in these markets. This should reduce the cost of lending for farmers. By April 2003, the pilot reforms had been replicated in 92 counties across China (Cheng and Xu 2003).

However, this reform has its own problems. The increase in deposit rate for rural credit cooperatives has shifted savings deposits from other financial institutions to rural credit cooperatives. But rural credit cooperatives are restricted to lending to 
rural households and enterprises in their local townships. Some rural credit cooperatives, therefore, have difficulty lending out the high-cost funds profitably, as the increases in the lending rates of rural credit cooperatives are determined more by the competition on the local markets than the costs and risks of rural credit cooperative operations. In the townships where there is little competition from other formal financial institutions and informal sources of finance, rural credit cooperatives tend to raise their lending rate to the maximum 100 per cent over the base rate. Rural credit cooperatives have difficulties raising their rate to the maximum where they face extensive competition. Further research is needed to study the impacts of partial interest rate liberalisation on rural credit cooperatives, other financial institutions and the local economy.

\section{Microfinance}

With financial support from the Canadian International Development Agency, the People's Bank of China started its own microfinance experiment with rural credit cooperatives in Luoping County of Hebei Province. It also issued an official document to promote micro-credit-particularly group guarantees and repayment in installments-and the connection between savings and loans (People's Bank of China Document 245 1999). Microfinance, as defined by the People's Bank of China, also includes the credit rating to individual households.

\section{CONCLUSIONS}

Since the mid 1990s, there has been a decline in the supply of institutional credit in rural China, caused by deterioration in loan quality, distortion in financial prices, a lack of competition in rural financial markets and problems associated with the ownership structure and corporate governance of rural financial institutions. Declines in the supply of institutional credit have had a negative impact on Chiria's rural economic development, particularly on the development of TVEs and rural off farmproduction, which used to be supported by the Agricultural Bank of China.

The microfinance movement initiated and funded by donors has tested lending methodologies and sustainable lending interest for microfinance programs in China. The main lessons are that

- the poor in many areas of China are bankable

- the current lending rates as regulated by the People's Bank of China are far below the sustainable rate for the operation of rural financial institutions in many areas of China 
- the mechanisms of microfinance, such as group guarantee, dynamic incentives and the targeting of women, help loan repayment in rural China. However, the experiment in microfinance has not been tested for long enough to be able to tell whether the new institutional form for delivering sustainable financial services to the poor will be successful in the long term. The movement has not been able to develop an external monitoring and auditing system to ensure the healthy development of the movement in the long term.

Government-initiated rural financial reforms have focused on institutional changes: the separation of the Agricultural Development Bank of China and rural credit cooperatives from the Agricultural Bank of China, commercialisation of the latter's operations, relaxation of direct state control over lending rates and provision of agricultural support on-lending to rural credit cooperatives. The recent pilots for the reform of rural credit cooperatives aimed to resolve the problems associated with moral hazard for rural credit cooperatives, low lending rates and low margins for the operation of rural financial institutions, the separation of management from monitoring and supervision of rural credit cooperatives and historical burdens for rural credit cooperatives. It remains to be seen what effect the reforms in Jiangsu and other parts of the country will have, or indeed whether these reforms will be replicable elsewhere.

\section{NOTES}

1 Rural credit foundations emerged in mid 1985, with strong support from local governments. For more information about rural credit foundations, see Cheng, Findlay and Watson (1997).

2 Park (1998:25) also found that lending is not profitable in rural China based on his field investigations in China.

3 For more detailed analysis of problems with centralisation and decentralisation of the $A B C$ and rural credit cooperatives, see Shen Minggao (2002).

4 Rural credit foundations emerged in the mid 1980s with strong support-and billions of yuan in deposits-from the Ministry of Agriculture and local governments. They were not financial institutions and, by law, not allowed to raise deposits from the public.

5 Since the rural economic reforms, there have been no bankruptcy cases for rural financial institutions, including any of the township level rural credit cooperatives that are legal persons and profit centres. The only exception is the rural credit cooperatives and urban credit cooperatives in Enping City of Guangdong Province (see Cheng and Xu 2003).

6 The Grain Bureau system did the same (see Cheng 1997). 
7 Assuming 30 per cent of the current rural credit cooperative loans cannot be collected (a conservative estimate), the overall amount of loans that need to be written off for the rural credit cooperative system will be around RMB 360 billion (US $\$ 45$ billion).

8 For details on China's microfinance movement see Park and Ren (2001) and Cheng (1998; 2003).

9 Donor-funded microfinance programs are not allowed to organise voluntary savings from the public.

10 See CGAP 2000. Operational sustainability here refers to the incomes of microfinance institutions covering the operational costs, loan loss provisions and real fund costs (usually subsidised, not opportunity cost of capital).

11 For the problems with the mixed policy and commercial operation of the Agricultural Bank of China see Cheng 1997.

12 For the rural credit foundations and their collapse in the late 1990s see Cheng, Findlay and Watson 2003.

13 See PBOC Document 446, 1998.

${ }^{14}$ For detail on rural credit cooperatives and reforms see Watson 2003.

${ }^{15}$ For details on the Jiangsu pilot see Chu and Cheng 2003.

t6 In addition to Jiangsu, provincial rural credit cooperative federations were established in Beijing, Shanghai, Tianjin, Chonging and Ningxia on a pilot basis to separate bank monitoring and supervision from management.

${ }^{17}$ For rural commercial banks see Cheng and Chu 2003.

\section{REFERENCES}

Agricultural Development Bank of China, 1994. Zhongguo Nongye Fazhan Yinhang Jianjie [Annual Report], Agricultural Development Bank of China, Beijing.

Chen Jianbo, Feng Xiaoling and Yan Yuming, 1999. 'Guanyu Chongqingshi nongcun hezuo jijinhui qingli de diaocha [On the closure of RCFs in Chongqing City]', in Ma Hong and Wang Mengkui (eds), Zhongguo Fazhan Yanjiu [China Development Research], Zhongguo Fazhan Chubanshe, Beijing:447-52.

Cheng Enjiang, 1997. 'Market reforms and provision of credit for grain purchases in China', The China Quarterly, 151(September):633-53.

- 1998. 'Micro-finance', China Review, Spring:9-19.

- Findlay, C. and Watson, A., 2003. 'Institutional innovation without regulation: the collapse of Rural Credit Foundations and lessons for further financial reforms', in C. Findlay, A. Watson, Cheng Enjiang and Zhu Gang (eds), Rural Financial Markets in China, Asia Pacific Press, Canberra:89-104. 
_- 2003. 'Microfinance in Rural China', in C. Findlay, A. Watson, Cheng Enjiang and Zhu Gang (eds), Rural Financial Markets in China, Asia Pacific Press, Canberra:120-33.

- and Xu Zhong, 2003. Rates of Interest, Credit Supply and China's Rural Development, Working Paper, Centre for Strategic Economic Studies, Victoria University, Melbourne.

- and Chu Baojin, 2003. The Pilot Reforms in Jiangsu, an Introduction, Paper presented at the Workshop on China's Rural Finance, People's Bank of China, Beijing, 16-18 August 2003.

Chu Baojin and Cheng Enjiang, 2003. Co-operative to Stock Conversions: the case of three rural commercial banks in Southern Jiangsu, China, Paper presented at the Workshop on China's Rural Finance, People's Bank of China, Beijing 16-18 August 2003.

Consultative Group to Assist the Poorest (CGAP), 2000. Annual Report, Consultative Group to Assist the Poorest, World Bank, Washington, DC.

Dai Xianglong, 1997. Lingdao Ganbu Jinrong Chubanshe Zhishi Duben [Financial Knowledge for Leading Cadres], Zhongguo Jinrong Chubanshe, Beijing.

Findlay, C., Watson, A., Cheng Enjiang and Zhu Gang (eds), 2003. Rural Financial Markets in China, Asia Pacific Press, Canberra.

He Guangwen, 2001. 'Zhongguo nongcun jinrong gongqiu tezheng ji junheng gongqiu de lujing xuanze [The characteristics of supply and demand for rural finance in China and the choices of ways to balance them]', Zhongguo Nongcun Jingji [Chinese Rural Economy], 10:40-5.

Li Jing, 2000. 'Give more credit service to countryside - A survey in Tunwa village in Shanxi Province', China Rural Survey, 3.

McKinnon, R.I., 1973. Money and Capital in Economic Development, The Brookings Institution, Washington, DC.

Ministry of Agriculture, 2002. A report on rural financial services, Department of Industrial Policy, Law and Policy, Ministry of Agriculture (unpublished).

Park, A., 1998. Rural financial market development in China: a report to the World Bank, Working Paper, Department of Economics, University of Michigan, Ann Arbor (unpublished).

Park A., and Ren, C., 2001. 'Microfinance with Chinese Characteristics', World Development, 29(1):39-62.

Shaw, E.S., 1973. Financial Deepening in Economic Development, Oxford University Press, Oxford. 
Shen Minggao, 2002. Decentralization in financial institutions: theory and evidence from China, PhD Thesis, Stanford University, Stanford (unpublished).

Tongren PBOC (2001), 'The Development Path of RCCs in less developed areas', Financial Reference, September 2001.

Watson, A., 2003. Financing Farmers: the reform of the rural credit cooperative and the provision of financial services to farmers (unpublished).

Wen Tie-jun, 2001. The Increasing Rural Usuries: the current situation, problems and policy suggestions, Research Report, Monetary Policy Committee, People's Bank of China, Beijing.

Woo Wing Thye, 2003. China's Rural Enterprises in Crisis: the role of inadequate financial intermediation, Paper presented at the Financial Sector Reform in China conference, Kennedy School of Government, Harvard University, Harvard, 1113 September 2001.

Xie Ping, 2001. 'Zhongguo nongcun xinyong hezuoshe tizhi gaige de zhenglun [Debates on the structural reform of China's Rural Credit Cooperatives]', Jinrong Yanjiu [Journal of Financial Research], 1:1-13.

Xie Ping, 2002. Reforms of China's Rural Credit Cooperatives and Policy Options, Paper presented to the World Bank Workshop on China's Rural Finance, The People's Bank of China, Beijing, 2003.

Zhang Xiaoshan, 2003. 'Deepening Rural Reforms and Promoting Rural Economic Development', China's Rural Economy, 2003, $1^{\text {st }}$ Issue. 